\title{
Local knowledge on rice variations (landraces) of the Naga Community, West Java, Indonesia
}

\author{
SIDIK PERMANA ${ }^{1}$, JOHAN ISKANDAR $^{2, \boldsymbol{\varphi}}$, PARIKESIT $^{2}$ \\ ${ }^{1}$ Environmental Study Master Program, Universitas Padjadjaran. Jatinangor, Sumedang 45363, West Java, Indonesia \\ ${ }^{2}$ Department of Biology, Faculty of Mathematics and Natural Sciences; and Postgraduate of Environmental Science (PSMIL \& DIL) and Institute of \\ Ecology (PPSDAL), Universitas Padjadjaran. Jl. Raya Bandung-Sumedang Km21, Jatinangor, Sumedang 45363, West Java, Indonesia. Tel: +62-22- \\ 77912. ^email: johan.iskandar@unpad.ac.id
}

Manuscript received: 14 November 2017. Revision accepted: 5 April 2018.

\begin{abstract}
Permana S, Iskandar J, Parikesit. 2018. Local knowledge on rice variations (landraces) of the Naga Community, West Java, Indonesia. Asian J Ethnobiol 1: 1-8. Ethnobotanical studies have indicated that diversity of local varieties of crop plants and associated local knowledge has seriously eroded in many developing countries across cultures, including West Java, Indonesia, due to many factors such as agricultural modernization, development of market economy, government policies, and human population increase. This paper gives an account of the local knowledge or the traditional ecological knowledge (TEK) about the rice varieties (landraces) of the wet rice fields, management of wet rice farming, and also factors influencing local knowledge of rice landraces of the wet rice fields of the Naga community, West Java, using a combination of qualitative and quantitative ethnobotanical methods. The study results show that the Naga community has still maintained a rich TEK on local rice landraces. About 15 landraces of wet rice have been recorded, distinguished by the Naga community based on traditional knowledge. They also manage various local rice landraces and wet rice farming activities, including seed selection, preparing nursery and land, planting, crop and pest management, and harvesting and storing harvested rice based on the TEK embedded in their culture.
\end{abstract}

Keywords: Ethnobotany, local knowledge, Naga community, rice landraces, wet rice field, West Java

\section{INTRODUCTION}

The local village communities of West Java owned local knowledge, also called local ecological knowledge or traditional ecological knowledge (TEK), on local crop varieties (landraces) and local ecosystems, which are deeply embedded in their culture. These traditional ecological knowledge models have been inherited from their ancestors and orally transmitted intergenerational using the local language or mother tongue (Iskandar 2012). Further, traditional ecological knowledge is not static but dynamic due to continuous and intense interactions between local communities and the environment. This knowledge may be embedded in Western scientific knowledge by selecting and introducing external information (cf. Iskandar and Ellen 2007).

One of the traditional ecological knowledge models is regarding the rice varieties. The Naga community usually cultivates various rice varieties or landraces, adapted to local ecosystems based on TEK. Initially, mainly the local rice varieties were farmed in the sawah agroecosystem of West Java (Iskandar and Ellen 1999; Iskandar 2012). The word landrace is used for rice varieties or categories (following Siegeta 1996; Brush 1991, see also Iskandar and Ellen 1999) used by the local people of West Java to distinguish them from 'varieties' in the conventional Western taxonomic sense. Thus, in this context, a landrace is a local rice category according to characteristics reflected in the specific vernacular names.
The local knowledge or the traditional ecological knowledge on the local rice varieties of the wet rice fields is a dynamic system to adapt to the various ecological, socio-economic, and cultural changes. The traditional ecological knowledge has changed due to many factors, including human population increase, government policy, market, economic development, and the erosion of local languages (cf. Maffi 1999; Lizarralde 2004; Iskandar and Iskandar 2011). The local rice varieties of West Java have dramatically eroded due to modernization of the rice farming systems, such as introducing modern high yielding rice varieties, the introduction of pesticides, and inorganic fertilizers through the Green Revolution program since the 1960 s, etc. Consequently, some germplasm of local rice varieties of the wet rice field systems has wholly disappeared. Though the people of the Naga community have adopted Green Revolution in general, they have culturally maintained the various local rice varieties (landraces). The local rice varieties have been integrated with the modern rice varieties. As a result, both the local rice varieties and the contemporary rice varieties are cultivated in the wet rice field system of the Naga community. Some research on the local rice varieties has been carried out by scholars, such as Iskandar and Ellen (1999), Warsiti (2009), and Tarigan (2013). Those researches have not focused on integrating the local rice varieties and modern rice varieties farmed in the rice field system. This paper provides an account of the local knowledge or the traditional ecological knowledge (TEK) on the management of rice varieties (landraces) and factors 
influencing the local expertise on rice landraces of the wet rice field of the Naga community, West Java. The worldview of the Naga community on rice will be elucidated in this paper.

\section{MATERIALS AND METHODS}

\section{Location and people}

This research was conducted in Naga Hamlet in Neglasari Village, Salawu sub-district, Tasikmalaya District, West Java, Indonesia. Geographically, the Naga hamlet is located in the hilly upland area, between Garut and Tasikmalaya districts (Figure 1).

The distance from the town of Tasikmalaya to Naga village is approximately $30 \mathrm{~km}$, while the distance from the city of Garut is about $26 \mathrm{~km}$. To reach the Naga hamlet from the parking area of vehicles, people must walk using a footpath down the valley for approximately 20 minutes.

The altitude of Naga hamlet is $690 \mathrm{~m}$ above sea level. It has an air temperature between $21.5^{\circ}$ and $23^{\circ}$ Celsius. The Naga has a total area of about 10.5 hectares.

The land use of Naga hamlet can be divided into five types, namely hamlet area, wet rice field, garden and mixed garden, river, and protected forest. The hamlet area consists of traditional houses made of bamboo and wood with roofing of Arenga leaf and fiber and the home garden. The home garden consists of sheep cages and the mortar for pounding rice, along with the fish ponds (Figure 2. A). The wet rice fields are located outside the hamlet area, while the gardens and mixed gardens are located in the hilly area The traditional protected forest is situated outside the hamlet's riverbank (Figure 2. B).
According to the ecological history, the recorded initial population of the Naga community in 1921 was only 35 individuals. In 1984 and 1985, the people of the Naga community were 351 individuals and 353 individuals, respectively. Recently, the population of the Naga community was registered in 2013 , which includes a total of 325 individuals representing 108 households (Table 1).

It can be seen from Table 1 that the population of the Naga community has increased between 1921 and 2013. However, the population has registered a decrease between 1985 and 1994 due to migration to neighboring areas or urban areas, particularly the Naga people who do not like to keep their original culture. In other words, the people who are presently residing in the Naga hamlet have still maintained their traditional culture as a community.

The main subsistence activity of the Naga community is farming that involves cultivating the wet rice fields, gardens, and mixed-gardens. They also traditionally keep some livestock, namely local chicken, sheep, and fish, in the fish ponds. In addition, they have off-farm activities such as making bamboo artifacts, peddling, and running a small business in shops (warung).

Table 1. The population of the Naga community, Neglasari, Tasikmalaya, West Java, Indonesia, from 1921 to 2013.

\begin{tabular}{lll}
\hline Year & Population & Households \\
\hline 1921 & 35 & - \\
1984 & 351 & - \\
1985 & 353 & - \\
1994 & 314 & 97 \\
2001 & 326 & - \\
2011 & 305 & 103 \\
2013 & 325 & 108 \\
\hline Note: (-) data not available. Source: Suganda (2006), and the \\
hamlet statistical data of Naga (2013)
\end{tabular}
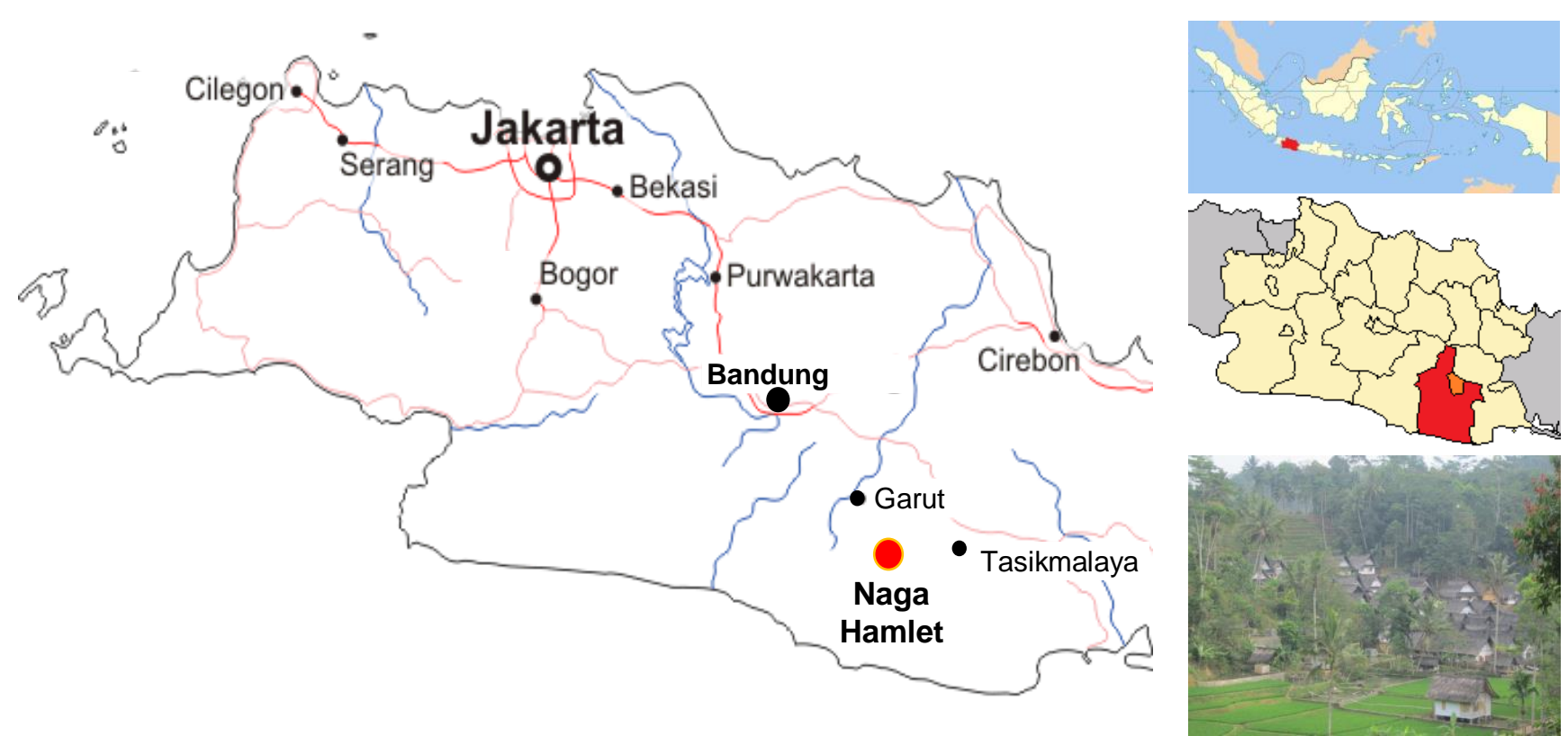

Figure 1. Location map of the Naga Hamlet, Neglasari Village, Salawu Subdistrict, Tasikmalaya District, West Java, Indonesia 

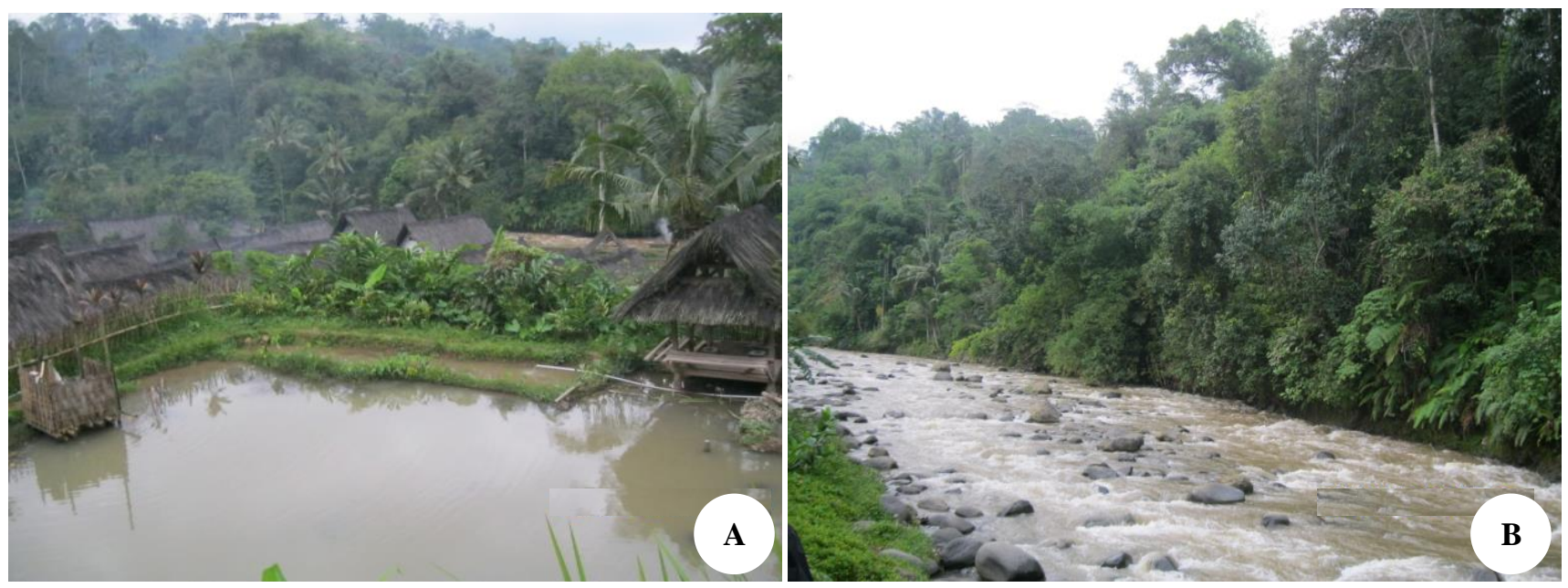

Figure 2. A. The hamlet of Naga community, West Java, Indonesia, consists of the traditional houses, the sheep cage, and fishpond. B. The conventional protected forest located on the riverbank outside the settlement area

\section{Method}

The method used in this study was a combination of the qualitative and quantitative techniques with the ethnobotanical approach (Martin 1995; Iskandar 2012). Several techniques, namely observation, semi-structured interview or in-depth interview, and structured interview, were applied. Observation was used to obtain general information on the settlement conditions, wet rice field, garden and mixed-garden, and the protected forest. The semi-structured interview with the informants was purposively selected based on completeness and categorization (Bernard 1994; Iskandar 2012). The informants were selected by the snowball technique based on the initial referrals given by the informal leaders. The informants consisted of aged men and women farmers, circumcisers (dukun or paraji sunat), healers (dukun jampe), a guardian of the grave or sacred place (kuncen), a hamlet leader (tua kampung), and the village staff (perangkat desa). Meanwhile, the structured interviews were undertaken with the randomly selected household. The number of respondents was decided using the statistical formula of Lynch et al. (1974 cited by Iskandar 2012) given below:

$$
n=\frac{N \cdot Z^{2} \cdot P \cdot(1-P)}{N \cdot d^{2} \cdot+Z^{2}(1-P)}
$$

Where:

$\mathrm{n}=$ Number of Respondents

$\mathrm{N}=$ Total number the households

$\mathrm{Z}=$ value of normal variable (1.96)

$\mathrm{P}=$ proportion of maximum probability $(0.50)$

$\mathrm{D}=$ error $(0.10)$

The total registered households of the Naga community were 108 , and the number of respondents calculated by the statistical formula was 34 , as shown below:

$$
\begin{aligned}
& \mathrm{n}=\frac{108 \cdot(1,96)^{2} \cdot 0,50 \cdot(1-0,50)}{108 \cdot(0,10)^{2}+(1,96)^{2}(1-0,50)} \\
& \mathrm{n}=34
\end{aligned}
$$

\section{Data analyses}

The qualitative data were analyzed during and after the field research. The data collected in the field and obtained from different sources, such as interviews, were continuously cross-checked. Moreover, the data were categorized and reduced based on relevance to the study's objectives (Moleong 2004; Iskandar 2012). The o data was interpreted regarding its consistency based on two perspectives, namely the informant perceptions (emic view) and scientific analysis by researchers (etic theory) (Iskandar 2012). Then the data was narrated with descriptive and evaluative research (cf. Newing et al. 2011). Meanwhile, the quantitative data were also statistically analyzed by calculating the percentage of the respondents answering each question of the questionnaire, presented in tables and charts, and narrated with descriptive and evaluative analysis.

\section{RESULTS AND DISCUSSION}

\section{Source of the TEK on the rice landraces}

The Naga people of West Java have obtained their traditional ecological knowledge (TEK) on the landraces of the local rice by intergenerational inheritance from their ancestors, and it's the result of a long process of cultural adaptations with the local environmental conditions. Of the 34 respondents of the Naga community who participated in the study, 28 respondents or $82.35 \%$ have obtained their TEK on the landraces of local rice from their parents and 3 $(8.82 \%)$ from their neighbors or other people, and 1 $(2.94 \%)$ from friends/relatives (Table 2). 2 respondents do not know the actual source of their TEK. 
As shown in Table 2, there is no doubt that the parents have an essential role in transmitting the TEK. Therefore, we agree with Boyd and Richerson (1985) and Hewlett and Cavalli-Sforza (1986 quoted by Puri (1997) that village people learn the TEK by three general processes, which can be labeled as parental, peer, and individual learning. Parental learning involves fathers, uncles and aunts, and other elders teaching young boys and girls. Learning at this stage is equivalent to 'vertical cultural transmission' because socially transmitted knowledge is passed from generation to generation or inter-generational. Peer learning occurs in a group of young farmers, from roughly fourteen to seventeen. Afterward, boys or girls start to learn alone. Learning at this stage is equivalent to 'horizontal cultural transmission' because it occurs between members of the same generations or intra-generational. Meanwhile, individual learning takes place as adults, who often prefer to learn alone, before they have children to teach, and the children join rice farming activities with their peers and parents (cf. Puri 1997).

Traditionally, although the community of Naga has a low formal education, people have deep traditional ecological knowledge on landraces of rice and the practice of rice farming, which is originated from these three stages of learning, namely parental, peer, and individual learning.

\section{The TEK on rice landraces}

Based on the intensive field research, TEK on 15 landraces of local rice (Oryza sativa L) commonly cultivated by the Naga community in the wet rice fields (sawah) has been recorded. These rice landraces are generally named as the pare ageung/ranggeuyan consisting of pare cere hideung, pare cere bodas, pare gantang, pare jamblang kuas, pare jamblang rancung, pare lokcan, pare jengkol, pare jidah nangka, pare peuteuy, pare regol, pare sarikuning, pare srek-srek bodas, pare srek-srek beureum, pare ketan bodas and pare ketan hideung. The 15 recorded landraces of local rice are locally categorized (the folk taxonomy) or distinguished based on 11 criteria, namely seed shape, seed color, hairy (buntutan) and non-hairy (teu buntutan) nature of the seed, presence of long hair and ordinary hair, the color of seed hair, the hulled rice color (warna beas), culinary character, nature of stem branching (cangcian), rice stalk color (barungbung), leaf shape, grain color (ranggeuyan pare), easily fall out and not easily fall out feature, and the ecological characteristics needed for proper growth in the fields (Table 3).

Table 2. The sources of the TEK of Naga people, West Java, Indonesia on landraces of local rice

\begin{tabular}{lcc}
\hline Sources of the TEK & $\begin{array}{c}\text { Respondent } \\
\text { number }\end{array}$ & $\begin{array}{c}\text { Percentage of } \\
\text { the total }\end{array}$ \\
\hline Parents & 28 & 82.35 \\
Relatives and friends & 1 & 2.94 \\
Neighbors/other people & 3 & 8.82 \\
Do not know/do not answer & 2 & 5,88 \\
Total & 34 & 100,00 \\
\hline
\end{tabular}

On the basis of ecological characteristics, the wet rice field (sawah) can be divided into 5 categories, namely sawah hieum, sawah ledok, sawah negrak, sawah angar, and sawah bebedahan. Sawah hieum is related to the wet rice field in the hillsides and shaded tree canopies and getting shine. Sawah ledok deals with the wet rice field with fertile soil, with enough water and sunlight. Sawah negrak is concerned with the wet rice field that has fertile soil and enough sunlight. Sawah angar may be defined as a damp rice field with dry soil and is less productive. Meanwhile, sawah bebedahan may be defined as the wet rice field that is newly established, low fertile soil, to be fertile soil, so it must be fallowed between 1 and 1.5 years. Among 5 categories, the best sawah that is considered ideal for farming the rice is sawah ledok.

Meanwhile, the sawah hieum category is only suitable for planting rice of rek-srek. This rice landrace is perceived as resistant to the lack of sunlight caused by the vegetation shading. Nowadays, the Naga community introduces new rice varieties called pare segon, including Ciherang, Sarinah, and IR-64. Those rice varieties are predominantly cropped in the wet rice fields of a lack of water (sawah anggar), high sunlight, and a high air temperature. The age of new rice varieties (pare sengon) is relatively short of the average between 3 and 4 months.

Based on the Western scientific knowledge (etic view), the rice crop (Oryza sativa L) can be divided into two significant varieties, namely indica and japonica (Fox 1991). In addition, another variety of rice named javanica is also known (Table 4).

It can be seen from Table 4, based on the TEK of the Naga community, the rice can be divided into two major types, namely, pare ageung or pare ranggeuyan (local varieties) and pare unggul, pare pendek or pare segon. The first type of rice, pare ageung, is predominantly grown by the Naga community in the wet rice fields of the upland area with low sunlight (hieum) and relatively cool air temperature. Meanwhile, the second type of rice, pare unggul or pare pendek, is commonly planted by the Naga community in the wet rice fields of the flat and open areas (sawah datar/sawah negrak) (cf. Siregar 1981; Iskandar 2001 cited by Warsiti 2009, Iskandar 2012). The pare unggul type needs high sunlight, warmer air temperature, and has a short harvesting time of about 100 days (Iskandar 2012). In general, planting pare segon/pare pendek varieties is commonly done in the wet rice fields of nonshaded (sawah negrak) areas, which is in line with the botanical knowledge (Western Scientific) knowledge) that these rice varieties need high sunlight. In other words, though the traditional ecological knowledge of the Naga community and the Western Scientific knowledge has a different origin (the Naga community knowledge is based on empirical experiences of trial and error and the Western Scientific knowledge is theoretical), the understanding about the appropriate places needed for proper growth of various rice varieties is generally the same (cf. Berkes and Gadzil 1995). 
Table 3. Characteristics of landraces of local rice in the TEK of the Naga community, West Java, Indonesia

\begin{tabular}{|c|c|c|c|c|c|}
\hline Local name & Hairy/non-hairy & Seed color & Hulled rice color & $\begin{array}{l}\text { Ecological } \\
\text { characteristics*) }\end{array}$ & $\begin{array}{l}\text { Culinary } \\
\text { Feature }\end{array}$ \\
\hline Cere bodas & Non-hairy & Yellow & White & SL, SA, SN, SB & Sticky \\
\hline Cere hideung & Non-hairy & Black & White & $\mathrm{SL}, \mathrm{SA}, \mathrm{SN}, \mathrm{SB}$ & Sticky \\
\hline Gantang & Hairy & Yellow & Red & SL, SA, SN, SB & Tasty \\
\hline Jamblang kuas & Hairy & Yellow & White & SL, SA, SN, SB & Ordinary \\
\hline Jamblang rancung & Hairy & Yellow & White & $\mathrm{SL}, \mathrm{SA}, \mathrm{SN}, \mathrm{SB}$ & Ordinary \\
\hline Loccan & Hairy & Yellow & White & $\mathrm{SL}, \mathrm{SA}, \mathrm{SN}, \mathrm{SB}$ & Ordinary \\
\hline Jengkol & Hairy & Yellow & White & SL, SASN, SB & Ordinary \\
\hline Jidah nangka & Hairy & Yellow & White & $\mathrm{SL}, \mathrm{SA}, \mathrm{SN}, \mathrm{SB}$ & Ordinary \\
\hline Peuteuy & Non-hairy & Yellow & White & $\mathrm{SL}, \mathrm{SA}, \mathrm{SN}, \mathrm{SB}$ & Ordinary \\
\hline Regol & Hairy & Yellow & White & $\mathrm{SL}, \mathrm{SA}, \mathrm{SN}, \mathrm{SB}$ & Ordinary \\
\hline Sarikuning & Hairy & Yellow & White & SL, SA, SN, SB & Ordinary \\
\hline Srek-srek bodas & Hairy & White & White & SH & Ordinary \\
\hline Srek-srek beureum & Hairy & Red & White & SH & Ordinary \\
\hline Ketan bodas & Non-hairy & Yellow & White & $\mathrm{SL}, \mathrm{SA}, \mathrm{SN}, \mathrm{SB}$ & Tasty, Sticky \\
\hline Ketan hideung & Non-hairy & Black & Black & $\mathrm{SL}, \mathrm{SA}, \mathrm{SN}, \mathrm{SB}$ & Tasty, Sticky \\
\hline
\end{tabular}

Table 4. Two wide rice varieties of the Naga community, West Java, Indonesia

\begin{tabular}{lll}
\hline $\begin{array}{l}\text { Rice varieties based on the Naga } \\
\text { community classification (emic view) }\end{array}$ & Characteristics & $\begin{array}{l}\text { Rice varieties based on Botanical } \\
\text { classification (etic view) }\end{array}$ \\
\hline Local varieties (pare ageung, ranggeuyan) & $\begin{array}{l}\text { Relatively long-maturing, sturdy, wide-leaved } \\
\text { rice with long panicles, large and bold grains, and } \\
\text { low photoperiod sensitivity }\end{array}$ & Javanica \\
$\begin{array}{l}\text { The superior varieties (pare unggul, pare } \\
\text { pendek) }\end{array}$ & $\begin{array}{l}\text { Narrow leaves, shorter culms and panicles, and } \\
\text { slender grains, and often photoperiod sensitive }\end{array}$ & Indica \\
\hline Source: Fox (1991), Inan and Purbayanti $(2008)$
\end{tabular}
Source: Fox (1991), Irawan and Purbayanti (2008)

About the diversity of rice varieties (landraces), the 7 landraces (ala) have been recorded from the Alune community of Pulau Seram (Suharno 213), which is lower than that of the Naga community, which has 15 landraces of rice. The diversity of rice landraces of Naga community, however, is lower than that of the Rancakalong community of Sumedang, from which 22 landraces (Warsiti 2009 and Baduy community of Banten from which 89 huasan pare (landraces of rice) have been reported (Iskandar and Ellen 1999). According to ecological history, the Naga had a high diversity of landraces in the past. However, some landraces of local rice disappeared (Table 5) because of many factors, including the introduction of new rice varieties and the selection process undertaken by the Naga people. The Government-sponsored Green Revolution Program has predominantly carried out the intensive introduction of new rice varieties in the Naga area since the late 1960s.

Initially, the Naga community rejected the modernization and introduction of new rice varieties due to the fear of disturbance to the environment. However, after the local government of Tasikmalaya, in cooperation with village staff, provided motivation and subsidized the seeds of new rice varieties, pesticides, and inorganic fertilizers to the Naga people, they accepted the modernization of the rice farming (Tarigan 2013). Due to this, some local rice varieties, including salak, goyot, and geulis (Table 4), disappeared from the Naga area. The introduction of the high-yielding rice varieties through the Green Revolution has caused the erosion of the local rice varieties that were adapted adequately to both local ecosystems and sociocultural conditions of the local people. In other words, various local rice varieties had been cultivated by local people of the Naga hamlet based on the traditional ecological knowledge in robust embedded with local culture in different local environments of the rice fields, including local soil conditions for a long time (cf. Brush 2004). Since the local community has adopted those local rice varieties to local ecosystems for a long time, the local people's capital infestation, knowledge, and ability are given for a long time (cf. Brush 2004). The consequence of the disappearance of the local rice varieties being replaced by the high-yielding rice varieties is the disappearance of associated traditional ecological knowledge of the local community farming those local varieties. 
Table 5. Some introduced new rice varieties, and some disappeared, local rice varieties of the Naga community of West Java, Indonesia

\begin{tabular}{ll}
\hline $\begin{array}{l}\text { Introduced } \\
\text { rice varieties }\end{array}$ & $\begin{array}{l}\text { Disappeared local } \\
\text { rice varieties }\end{array}$ \\
\hline IR-64 & Salak \\
Ciherang & Goyot \\
Septinah & Geulis \\
Bepak & Torondol \\
Royal & Jambu \\
Warneng & Nemol \\
Sinatnur & Kalapa \\
Jalur & Gadog \\
OR & Tamiang \\
Cisadane & \\
Bengawan & \\
Deris & \\
\hline
\end{tabular}

\section{Management of the rice farming}

The Naga community in the wet rice field (sawah) agroecosystem has culturally farmed both the local and the high-yielding rice varieties. Culturally, the management of rice farming in the sawah agroecosystem consists of various stages like seed selection, nursery preparation, land preparation, planting, looking after planted rice, preventing pests, harvesting, and storage of harvested rice.
The annual farming activities of the Naga community have been culturally based on the agricultural calendar (pranata mangsa). The pranata mangsa is used as the leading guide by the Naga community for determining the timing of each rice cultivation activity adapted to two main seasons, namely the wet and dry seasons (Figure 3).

The agricultural calendar of the Naga community is similar to that of Sundanese (cf. Iskandar 2012). This calendar is divided into twelve months, namely Kasa (June-July), Karo (August), Katiga (August-September), Kapat (September), Kalima (October-November), Kanem (November-December), Kapitu (December-February), Kawolu (February-March), Kasanga (March), Kasadasa (March-April), Desta (April-May), and Sada (May-June). Although currently, the weather, the climate, and the wet and dry seasons can hardly be predicted due to global warming, the Naga community has tried to apply the agricultural calendar with adaptations to dynamics of climatic changes. In addition, the predominance of the sounds of insects, namely turaes (Cryptotympana acuta) and tonggeret (Dundubia manifera), are used as indicators of the end of the rainy season and start of the dry season. The appearance of a constellation of the star of Kidang Kencana (the belt of Orion) is also commonly used as an indicator of the starting of the dry season.

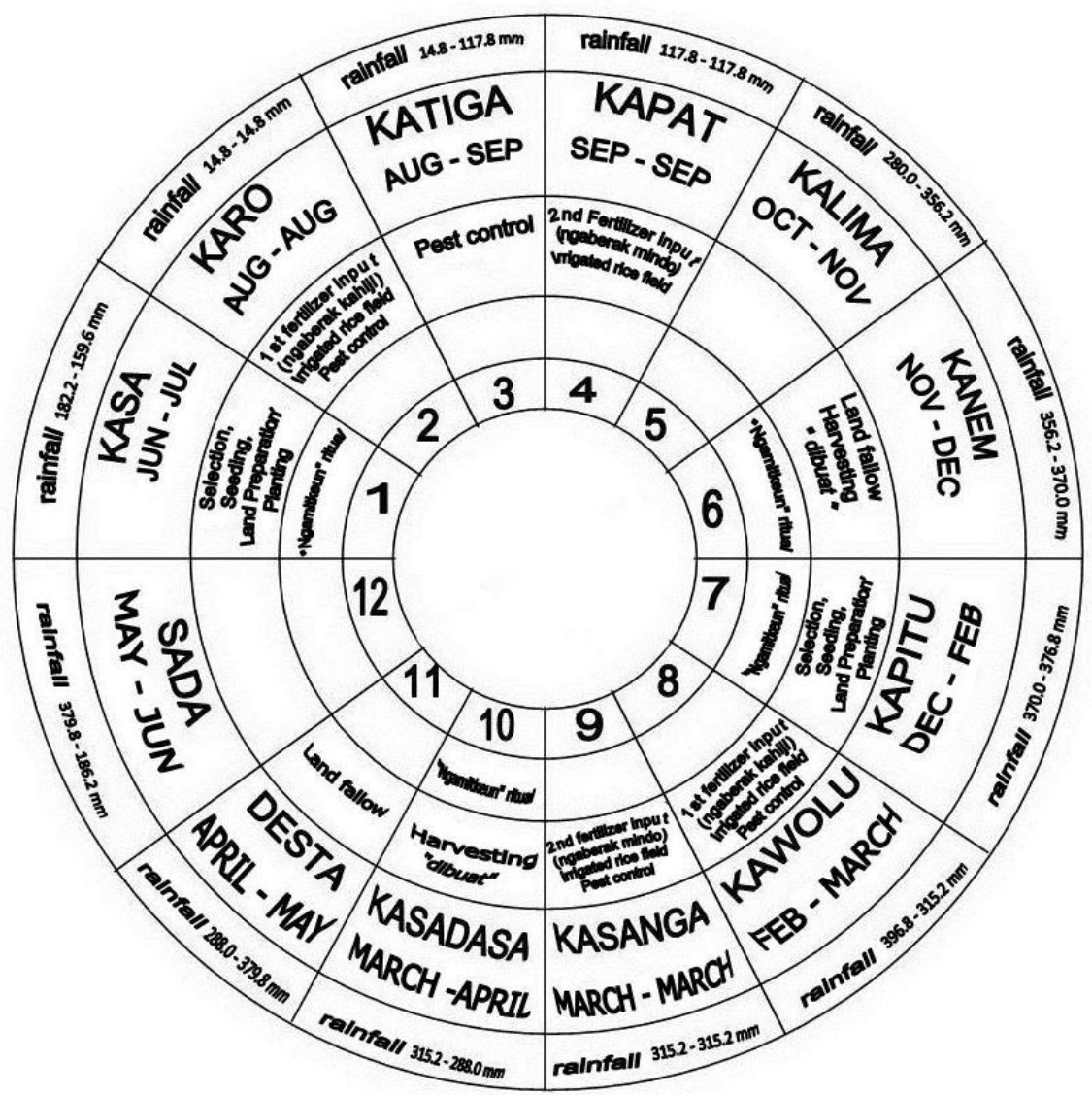

Figure 3. The agricultural calendar (pranata mangsa) of the Naga community, West Java, Indonesia 


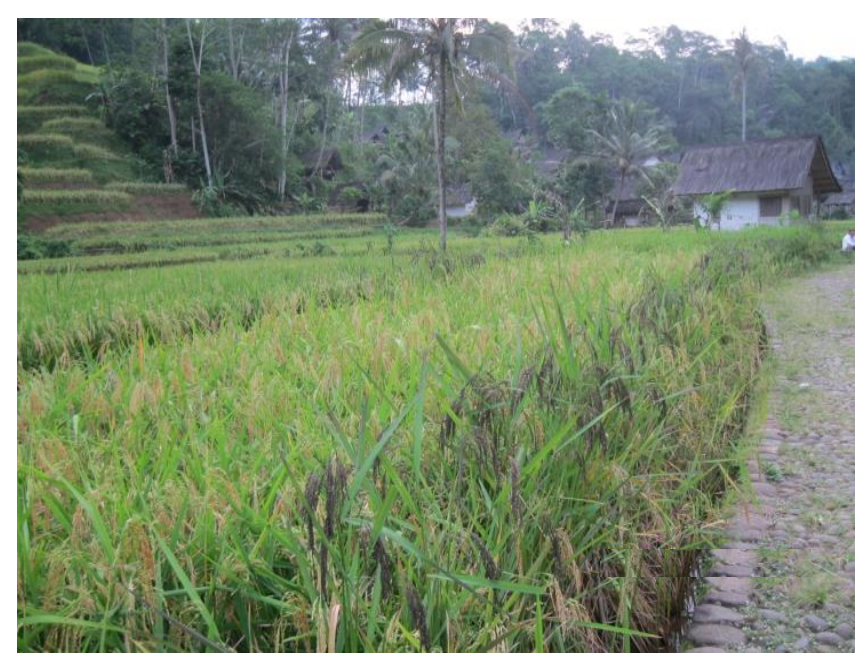

Figure 4. Several rice varieties are nearly harvested in the wet rice fields of the Naga community, West Java, Indonesia

On the basis of the rice farming practice, it can be noticed that though the Naga people are also growing highyielding rice varieties, they still practice rice farming based on their traditional ecological knowledge traditional agricultural calendar (Figure 3).

Before the 1980s, the Naga people cultivated only local rice varieties (landraces), which were planted in MarchApril (Mangsa Kasadasa) and September-October (Mangsa Kapat/Kalima) (Tarigan 2013). However, after adopting the Green Revolution in 1984, the local rice varieties are called padi lokal or pare ageung. The Naga community commonly cultivates the modern varieties or the high-yielding rice varieties. They produce local rice varieties (pare ageung) in the primary season called the tahun besar (taun ageung) and then cultivate the modern rice varieties called the tahun kecil (tahun alit). The use of the tahun besar and the tahun kecil is not concerning the low and high rainfall intensity, but by referring to the nature of rice varieties (local rice or modern rice) planted at that time. In the primary season or tahun besar (tahun ageung), the local rice varieties or padi lokal (pare ageung) are predominantly planted in June, July, August, September, and November. In January, February, and March, the modern rice varieties (pare pendek) are mainly planted and are called tahun kecil (tahun alit) (Figure 4). During April, May, and December, the wet rice fields are fallowed during the remaining months. This custom of the Naga community practicing rice farming by allowing a fallow time between has been considered a measure to maintain soil fertility. In addition, the new modern rice varieties are predominantly planted in the rainy season are intended to maximize rice production because these varieties require more water. On the contrary, the local rice varieties are mainly grown in the dry season, considering these varieties are adapted to a shortage of water in the wet rice fields (cf. Altieri 1990). According to Clawson (1985 cited by Altieri 1990), planting and managing different crop varieties and applying the fallow time can maintain these crop varieties by preventing pests and increasing crop harvest.

\section{Worldview of the Naga community on rice}

Like Sundanese village people in the past, the Naga community believes that rice has a goddess called Nyai Pohaci (cf. Prawirasuganda 1964; Wessing 1978). Nyai Pohaci is perceived as the fertility goddess who owns and protects rice. In addition, the Naga community believes that rice has its origin from parts of the eye and the heart of Nyai Pohaci. Each watch consists of a grain of rice consisting of a different color. The white grain of rice has originated from the white eyelids and the hairy black grain of rice from the eyelashes of Nyi Pohaci. In addition, the varieties of sticky rice (padi ketan) are believed to have come from the heart, and each array is composed of five grains of rice (Suganda 2006). As a result, the Naga community highly respects and appreciates the traditional rituals, such as planting and harvesting rice.

Based on this study, it can be concluded that the Naga community has a rich traditional ecological knowledge about rice varieties (landraces) and the sawah rice farming practice. This research also confirms the hypothesis that the ecosystems which have experienced the significant human presence and human resource use over time are biocultural systems - systems that have been shaped jointly by biological and cultural dynamics. This is not only in terms of causing environmental degradation and resource depletion but also in terms of human contributions, directly or indirectly, to the maintenance and even to the creation of biodiversity, including the local varieties of crops like rice, as presented in this study of Naga community (cf. Maffi 2004).

\section{ACKNOWLEDGEMENTS}

The authors wish to thank all the formal leaders, informal leaders, respondents, and informants of the Naga community who assisted and supported the research.

\section{REFERENCES}

Altieri MA. 1990. Why Study Traditional Agriculture?. In Carrol CR, Vandermeer JH, Rosset PM (eds.). Agroecology. McGraw Hill Book, New York.

Abdoellah OS, Hadikusumah HY, Takeuchi K, Okubo S, Parikesit. 2006. Commercialization of homegardens in an Indonesian village vegetation compositions and functional changes. In: Kumar BM, Nair PKR (eds.). Tropical Homegardens: A Time-Tested Example of Sustainable Agroforestry. Springer, Berlin. DOI: 10.1007/978-14020-4948-4_13.

AIPI. 2014. Panel Discussion: Development of ethnobotany in Indonesia. Jakarta 01 January 2014, 10: 53. [Indonesian]

Bernard HR.1994. Research method in anthropology: qualitative and quantitative approach. Sage Publications, London.

Berkes F, Folke C, Gadgil M. 1995. Traditional ecological knowledge, biodiversity, resilience, and sustainability. In: Perrings CA, Maler KG, Folke C, Holling CS, Jansson BO (eds.) Biodiversity Conservation. Kluwer Academic Publishers, Dordrecht, Nederland. DOI: 10.1007/978-94-011-0277-3_15.

Boyd R, Richerson PJ. 1985. Culture and Evolutionary Process. University of Chicago Press, Chicago.

Brush SB. 1991. A farmer-based approach to conserving crop germplasm. Econ Bot 45 (2): 153-165. DOI: 10.1007/BF02862044 
Brush SB. 2004. Farmers bounty: locating crops diversity in the contemporary world. Yale University Press, USA. DOI: 10.12987/yale/9780300100495.001.0001.

Creswell JW. 2012. Research design: qualitative, quantitative, and mixed approaches. Pustaka Pelajar, Yogyakarta. [Indonesian]

Fox JJ. 1991. Managing the ecology of rice production in Indonesia. In: Hardjono J (ed). Indonesia: resources, ecology. and environment, Oxford University Press, Singapore.

Hehakaya MA.2010. Study on Local knowledge of the people on varieties, usability, processing, and cultivation of banana plants (Musa spp) in the Sukajaya Village, South Sumedang Sub-district, Sumedang District. [Thesis]. Department of Biology, Padjadjaran University, Sumedang. [Indonesian]

Hewlet BS, Cavalli-Sforza LL. 1986. Cultural transmission among Aka Pygmies. Amer Anthropol 88: 922-934. DOI 10.1525/aa.1986.88.4.02a00100.

Irawan B, Rahmayani E, Iskandar J. 2009. Study on variations, utilization, and management of Aren in Rancakalong village, Rancakalong Subdistrict, Sumedang District, West Java. Seminar on Ethnobotany IV, 18 May 2009, Cibinong. [Indonesian]

Iskandar J. 2012. Ethnobiology and sustainable development. Puslitbang LPPM Unpad Bandung. [Indonesian]

Iskandar J, Ellen R. 1999. In situ Conservation of Rice Landrace among The Baduy of West Java. J Ethnobiol 19 (1): 97-125.

Iskandar J, Ellen RF. 2007. Innovation, 'hybrid' knowledge and conservation of relict rainforest in Upland Banten. In: Ellen R (ed), Modern crises and traditional strategies: local knowledge in Island Southeast Asia. Berhahn Books, New York.

Iskandar J, Iskandar BS. 2011.,Agroecosystem of Sundanese People. Penerbit Kiblat, Bandung. [Indonesian]

Lizarralde M. 2004. Indigenous knowledge and conservation of the rainforest: ethnobotany of the Bari of Venezuela. In: Carlson TJS Maffi L (eds), Ethnobotany and conservation of biocultural diversity. The New York Botanical Garden Press, New York.

Lynch SJF, Hoelnsteiner RM, Cover CL. 1974. Data gathering by social survey. Philippines Social Science Council, Quezon City.

Maffi L. 1999. Linguistic diversity. In Posey D. (ed), Cultural and spiritual values of biodiversity. Intermediate Technology Publication, London. DOI: 10.3362/9781780445434.002.

Maffi L. 2004. Maintaining and restoring biocultural diversity: The evolution of a role for ethnobiology. In: Carlson TJS, Maffi L (eds), Ethnobotany and Conservation of Biocultural Diversity. The New York Botanical Garden Press, New York.

Martin GJ. 1995. Ethnobotany: A Methods Manual \& Chapman \& Hall, London. DOI: 10.1007/978-1-4615-2496-0.

Matanubun H, Rochani A, Sumule. 1995. A. Some aspect of the indigenous knowledge of selected sweet potato farming system in
Irian Jaya. In: Schneider J. (ed.). Indigenous Knowledge in Conservation of Crop Genetic Resources. International Potato Center and Central Research Institutes for Food Crops, Bogor.

Moleong LJ. 2004. Qualitative Research Method. Remaja Rosda Karya, Bandung. [Indonesian]

Newing H, Eagle CM, Puri RK, Watson CW. 2011. Conducting research in conservation: a social science perspective. Routledge, London. DOI: $10.4324 / 9780203846452$.

Okubo S, Parikesit, Harashina K, Muhammad D, Abdoellah OS, Takeuchi K. 2010. Traditional Perennial Crop-based Agroforestry in West Java: The tradeoff between on-farm biodiversity. Agroforest Sys 80(1):1731. DOI 10.1007/s10457-010-9341-8.

Prawirasuganda A. 1964. Traditional ritual of Pasundan. Penerbit Sumur Bandung, Bandung. [Indonesian]

Puri RK. 1997. Hunting knowledge of the Penan Benalui of East Kalimantan, Indonesia. [Dissertation]. Department of Anthropology, University of Hawai'i, Hawai'i.

Rahayu M, Susiarti S, Sihotang VBL. 2012. A preliminary ethnobotanical study of useful plants by Local Communities Bodogol Lowland Forest, Sukabumi West Java. J Trop Biol Conserv 9 (1): 115-125.

Siegeta M. 1996. Creating landrace diversity: the case of the Ari people and ensete (Ensete ventricosum) in Ethiopia. In Ellen R, Fukui (eds). Redefining nature: ecology, culture, and domestication. Berg, Oxford.

Suharno, Wirawati DM. 2013. Seram island: imaging of its natural environment and the agricultural behavior of Alune people. Kepustakaan Populer Gramedia, Jakarta. [Indonesian]

Suganda H. 2006. Naga hamlet maintains the tradition. Penerbit Kiblat, Bandung. [Indonesian]

Fatriati T. 2008. Study on taxonomy of bamboo in Sumedang Sub-district based on morphological character and reed epidermal anatomy. [Hon. Thesis]. Department of Biology, Padjadjaran University, Sumedang. [Indonesian]

Tarigan, G.H. 2013. The changes in agricultural system of the Naga community, Neglasari village, Salawu Sub-district, Tasikmalaya District. [Thesis] Environmental Program Study, Padjadjaran University, Sumedang. [Indonesian]

Warsiti I. 2009. Management and Utilization of the local rice and factors affecting of conservation of the local rice varieties. [Thesis] Environmental Program Study, Padjadjaran University, Sumedang. [Indonesian]

Wessing R. 1978. Cosmology and social behavior in a West Javanese settlement. Ohio University Center for International Studies, Ohio.

Wirahman B. 2005. Study on taxonomy of Durian varieties in Subang District, West Java. [Thesis]. Department of Biology, Padjadjaran University, Sumedang. [Indonesian] 